\title{
Evaluation of antioxidant and phenolic contents of Zingiber montanum (J.Koenig) Link ex Dietr. : A potential ethomedicinal plant of Arunachal Pradesh, India
}

\author{
Aku Joram ${ }^{1}$, Arup K. Das ${ }^{2}$ and Debajit Mahanta ${ }^{1,3}$ \\ ${ }^{1}$ Centre of Excellence for Bioresources and Sustainable Development, DBT-APSCS\&T, Kimin 791121, \\ Papumpare District, Arunachal Pradesh, India \\ ${ }^{2}$ Department of Botany, Rajiv Gandhi University, Doimukh 791112, Arunachal Pradesh, India \\ ${ }^{3}$ Corresponding author,E-mail: debajit_m@yahoo.com
}

[Received 03.12.2018; Revised 21.12.2018; Accepted 26.12.2018; Published 31.12.2018]

\begin{abstract}
Zingiber montanum (J.Koenig) Link ex Dietr. (Zingiberaceae) is a medicinal plant used by the indigenous people of Arunachal Pradesh, India. The rhizome is properly washed and boiled or eaten raw during fever, cold and cough. It isalso reported to be used against Jaundice. The 2, 2 Diphenyl-1-picrylhydazyl (DPPH) antioxidant screening was done using DPPH free radical scavenging activity in methanol, petroleum, and chloroform extract. Folin-ciocalteu's phenol reagent is used to estimate total phenol content by using Gallic acid standard curve. The total phenolic content of Zingiber montanum in methanol, petroleum ether and chloroform extracts showed $0.40 \pm 0.004,0.35 \pm 0.002$ and $0.032 \pm 0.003 \mathrm{GAE} / \mathrm{g}$ respectively and antioxidant activity was found $29.1 \pm 0.03,40.9 \pm 0.04$ and $84.3 \pm 0.02$ in petroleum ether, chloroform and methanol extracts respectively which was compareble to the standard. Phytochemical screening also revealed the presence of alkaloids, saponins, tannins, flavonoids, terpenoid and phenolic compounds in its rhizome.
\end{abstract}

Key words: Ethnomedicinal, Zingiber montanum, Phenolic content, DPPH, Phytochemical Screening

\section{INTRODUCTION}

Zingiberaceae has held a place of importance for hundreds of years because the infusions and the tinctures of its numerous aromatic species, and are still used as components of herbal treatments for a variety of ailments. There are evidences of plant related aromatic compounds being used by almost all ancient civilizations, -the Indian, the Egyptian, the Babylonian, the Persian, the Jewish, the Chinese and even the Greek and the Roman civilizations (Bakhr 1992).

Zingiber cassumunar Roxb., which is synonymous with Zingiber montanum, has long been regarded by Thai massage therapists as one of those oils necessary to have in their kit to combat joint and muscle problems.

Native to Thailand, Indonesia and India, pale-amber oil is steam distilled from fresh rhizomes. It has a cool, green peppery aroma with pungent in taste. The main active chemical constituents of the oil are sabinene $(27-34 \%)$, g-terpinene $(6-8 \%)$, a-terpinene $(4-5$ $\%$ ), terpinen-4-ol (30 - 35\%), and (E)-1-(3,4 dimethoxyphenyl)butadiene (DMPBD) (12 $19 \%)$ (Casey et al. 1971). 


\section{STUDY AREA}

Lower Subansiri District covers an area of $1,317 \mathrm{sq} \mathrm{km}$, is bounded on the North by China and Upper Subansiri District, on the South by Papumpare District and Assam, on the East by West Siang and some part of Upper Subansiri and, on the West by East Kameng District of Arunachal Pradesh. Its Northeast boundary lies with the Tirap District of Arunachal Pradesh. (www.icssr.org/Executive\%20Summary\%20Lower\%20Subansiri.pdf)

The topography of the district is mostly mountainous and altitude varies approximately from 1000 to $1600 \mathrm{~m}$ above mean sea level. A greater part of it falls within the higher mountain zone consisting of tangled peaks and valleys. Nature has gifted the heartland of the District in the form of magnificent plateau at about $1564 \mathrm{~m}$ altitude, where District Headquarter, Ziro is located.

\section{METHODOLOGY}

\section{Collection and Processing of Plant Sample:}

The collection of the sample was done during the course of survey from the study area. The freshly harvested rhizomes were and air dried under shade for few days and then at $30^{\circ} \mathrm{C}$ in an oven. The dried samples were then powdered using a mixer-grinder and stored in air tight container and subjected for extraction and testing. The plant species was taxonomically identified with the help of taxonomist and following the Materials for Flora of Arunachal Pradesh and the nomenclature was updated as recorded in www.theplantlist.org.

\section{Determination of Stomatal Index:}

The stomatal index is the percentage of the number of stomata formed by the total number of epidermal cells including the stoma being counted as one cell (Salisbury 1927)

Stomatal index $=\mathrm{S} / \mathrm{E}+\mathrm{S} \times 100$

Where,

$\mathrm{S}=$ Total number of stomata in a given area of leaf

$E=$ Number of epidermal cells in the same area of leaf.

\section{Leaf Epidermal Hairs:}

For an epidermal hair there are two distinct parts the portions, embedded in the epidermis and termed as 'foot' and the free projecting portion termed as 'body'. The occurrence and the form of trichome are much valuable anatomical characters for the identification of leaves and the study was done following the standard method. (Small 1913).

\section{Root Anatomy:}

For microscopic study the roots were properly washed to remove the dirt. The transverse section of the required part was stained with saffranin and mounted with $90 \%$ glycerine.

\section{EXPERIMENTAL STUDY}

\section{Estimate of Moisture Content}

The moisture forms richest constituent of the total chemical composition in rhizome. It is also expressed as percentage and determined by AOAC methods (AOAC 1990). Here samples are weighed and placed in covered dishes in an oven at $105^{\circ} \mathrm{C}$ for overnight. Removing from dish and after cooling the sample again weighed for the difference from its earlier pre-drying weight.

QUALITATIVE PHYTOCHEMICAL SCREENING 
Moisture content $(\mathbf{\%})=\frac{\text { Weight of fresh samples }- \text { weight of dry samples }}{\text { Weight of fresh sample }} \times 100$

\section{Preparations of Extracts:}

The extracts were prepared following the methods as described by (Farnsworth 1969, 1988) and (Wall et al. 1953, 1954). 25g powdered material of each plant samples was extracted separately with $200 \mathrm{ml}$ of $95 \%$ methanol in soxhlet apparatus for 8hours. About $10 \mathrm{ml}$ of each of these extracts were kept separately for flavonoids test and the remaining portion of methanolic extract was evaporated to dryness under reduced pressure on water bath. Similarly the same part of plant species $(25 \mathrm{~g})$ was extracted in petroleum ether and chloroform.

\section{Test for Alkaloids:}

Solvent free extract, $50 \mathrm{mg}$ is stirred with few $\mathrm{ml}$ of dilute hydrochloric acid and filtered. The filtrate is tested carefully with various alkaloid reagents as follows:
a. Mayer's test (Evans 1997)
b. Wagner's test (Wagner 1993)

Test for Carbohydrates (Ramakrishnan et al. 1994):

The extract powdered $(100 \mathrm{mg})$ is dissolved in $5 \mathrm{ml}$ of water and filtered. The filtrate is subjected to the following tests
a. Molish's test
b. Fehling's test

Test for Glycosides (Ramakrishnan et al. 1994):

$50 \mathrm{mg}$ of the extract is hydrolyzed with concentrated hydrochloric acid for 2 hour on a water bath, filtered and the hydrolysate is subjected to the following tests.
a. Borntragers'test (Evans 1997)

Test for Saponins (Kolkate 1999):

The dried plant extract $(50 \mathrm{mg})$ is diluted with distilled water and made up to $20 \mathrm{~mL}$. The suspension is shaken in a graduated cylinder for 15 minutes. A two layer of foam indicates the presence of saponins.

Test for Protein (Fisher 1968):

The extract $(100 \mathrm{mg})$ is dissolved in $10 \mathrm{~mL}$ of distilled water and filtered through Whattman no. 1 filter paper and filtrate is subjected to tests for proteins.

\section{a. Biuret's test (Gahan 1984)}

An aliquot of $2 \mathrm{ml}$ of filtrate is treated with one drop of $2 \%$ copper sulphate solution .to this, $1 \mathrm{~mL}$ of ethanol (95\%) is added' followed by excess of potassium hydroxide pellets. Pink colour in the ethanolic layer indicates the presence of the protein.

Test for Phenolic Compounds and Tannin:

a. Gelatin test (Evans 1997)

b. Lead acetate test

Test for Gum and Mucilages (Whistler \& Bemiller 1993):

The extract (100mg) is dissolved in $10 \mathrm{ml}$ of the distilled water and to this; $25 \mathrm{~mL}$ of absolute alcohol is added with constant stirring. White or cloudy precipitate indicates the presence of gums and mucilages. 


\section{Test for Glycerol (lipid):}

Take $1 \mathrm{ml}$ of $1 \%$ copper sulphate solution in a test tube and add 5 drops of sample. Mix thoroughly and add 5 drops of the sample again mix thoroughly. Now add 5 drops $10 \%$ sodium hydroxide solution. A clear blue solution is obtained due to the formation of cupric hydroxide which indicates presence of glycerol.

\section{Determination of Total Phenolic Content:}

The amounts of total polyphenols in the plant extracts were determined by Folin-ciocalteu reagent method (Singleton \& Rossi 1965) and Galic acid was used as standard.

\section{Preparation of standard curve of Gallic acid:}

A solution of Gallic acid was prepared by dissolving $0.004 \mathrm{gm}$ Gallic acid in $250 \mathrm{ml}$ distilled water. From this 100 il $(0.0016 \mathrm{mg} / \mathrm{ml}), 200 \mathrm{il}(0.0032 \mathrm{mg} / \mathrm{ml}), 400 \mathrm{il}(0.0064 \mathrm{mg} / \mathrm{ml}), 600$ il $(0.0096 \mathrm{mg} / \mathrm{ml})$ and $800 \mathrm{il}(0.0128 \mathrm{mg} / \mathrm{ml})$ solution were taken in five different test tubes. Each solution is made up to $1 \mathrm{ml}$ with distilled water. To each of this tube then added $2 \mathrm{ml}$ saturated $\mathrm{Na}_{2} \mathrm{CO}_{3}(35 \%), 1 \mathrm{ml}$ Folin-ciocalteu reagent and then diluted to $6 \mathrm{~mL}$ with distilled water. The resulting mixtures were kept in dark for 60 minutes to develop a blue color. The absorbance of the mixtures was recorded at $760 \mathrm{~nm}$ versus prepared water blank.

After preparing the standard Gallic acid curve, the total amount of phenol in the plant extracts was determined as follows.

To $1 \mathrm{~mL}$ of dilute solution of each plant extract, $2 \mathrm{ml}$ saturated $\mathrm{Na}_{2} \mathrm{CO}_{3}(35 \%), 1 \mathrm{ml}$ Folin-ciocalteu reagent was added and then diluted to $6 \mathrm{~mL}$ with distilled water. The resulting mixture was kept in dark for 60 minutes to develop the blue color. The absorbance of the mixture was recorded at $760 \mathrm{~nm}$ by UV-visible spectrophotometer. The average of the triplicate measurements was used to calculate the phenolic content as mg Gallic Acid Equivalents (GAE)/g dry weight of the plant extract.

\section{Estimation of Carbohydrates:}

The amount of carbohydrate can be estimated using Anthrone method (Thimmaiah 1999). Weighted 100mg sample into boiling tube and hydrolyze by keeping it in a boiling water bath for 3 hour with $5 \mathrm{ml}$ of $2.5 \mathrm{~N} \mathrm{HCl}$ and cool to room temperature. It is then neutralized with sodium carbonate. Make up the volume to $100 \mathrm{ml}$ and centrifuged it. The supernatant is the collected and take $1 \mathrm{ml}$ aliquot for analysis. Prepare the standards and taking $0,0.2,0.4,0.6$, 0.8 and $1 \mathrm{ml}$ of the working standard. ' 0 ' serves as blank.

Now make the volume to $1 \mathrm{ml}$ in all the tubes by adding distilled water. Here added $4 \mathrm{ml}$ of Anthrone reagent and heated for $8 \mathrm{~min}$ in a boiling water bath. Cool rapidly and read the green to dark green color at $630 \mathrm{~nm}$ and absorbance putting on Y-axis where standard on $\mathrm{X}$ - axis on graph.

\section{Calculation}

$$
\text { Amount of carbohydrate }=\frac{\text { Sugar value from graph }(\mathrm{mg})}{\text { Volume of test tube }} \times 100
$$

\section{Antioxidant Assay:}

Phenolic have been reported to have a capacity to scavenge free radicals. The antioxidant activity of phenolic is mainly due to their redox properties, which allow them to act as reducing agents, hydrogen donators, and singlet oxygen quenchers. 


\section{The DPPH Assay:}

This method was given by Brand-Williams et al. (1995). It is one of the most extensively used antioxidant assays for plant samples.

Radical scavenging activity of extracts against DPPH (1, 1-Diphenyl-2-picrylhydrazyl) is determined spectrophotometrically at $\ddot{\mathrm{e}}=517 \mathrm{~nm}$ on a UV visible spectrometer as follows.

Stock solutions are prepared by dissolving $300 \mathrm{mg}$ of each crude extract in $10 \mathrm{~mL}$ methanol separately.

A solution of $0.004 \mathrm{~g}$ of DPPH $(\sim 1 \mathrm{mM})$ in $10 \mathrm{~mL}$ of the methanol was prepared daily before UV-measurement. From the stock solution for each measurements 200 il of DPPH solution is taken in the cuvette and made up to $3 \mathrm{~mL}$ by adding methanol. The absorbance recorded at $\ddot{e}=517 \mathrm{~nm}$. After that antioxidant activity of the extracts are studied by adding $100 \mathrm{il}, 200 \mathrm{il}, 300 \mathrm{il}, 400 \mathrm{il}$ of stock solution of the extracts, separately to the cuvette containing DPPH solution.

The solutions were kept in dark for $0 \mathrm{~min}$ and $30 \mathrm{~min}$ at room temperature and then decrease in absorbance is measured. Radical scavenging activity was calculated by the following formula.

Where,

$$
\% \text { inhibition }=[(\mathrm{Aa}-\mathrm{Ab}) / \mathrm{Aa}] \times 100
$$

$\mathrm{Aa}=$ absorbance of DPPH solution without plant extract $(\mathrm{t}=0)$

$\mathrm{Ab}=$ absorbance of DPPH solution in presence of plant extract $(\mathrm{t}=30$ minutes $)$.

\section{EXPERIMENTAL FINDINGS}

\section{Determination of Stomatal Index:}

The stomata present on both sides of leaf surfaces i.e., on adaxial and abaxial surfaces, the stomata is found to be diacytic or cross celled type in Z. montanum. The stomatal index of Z. montanum was found to be 4.16 (adaxial) and 8.69 (abaxial) respectively (Table 1).

Table 1. Results of Anatomical Studies

\begin{tabular}{|l|l|l|l|l|l|}
\hline Plant Species & $\begin{array}{l}\text { Leaf } \\
\text { surface }\end{array}$ & $\begin{array}{l}\text { Stomatal } \\
\text { type }\end{array}$ & $\begin{array}{l}\text { Stomatal } \\
\text { Index }\end{array}$ & $\begin{array}{l}\text { Type of } \\
\text { indumentum }\end{array}$ & $\begin{array}{l}\text { Moisture } \\
\text { content }\end{array}$ \\
\hline Z. montanum & Adaxial & $\begin{array}{l}\text { Diacytic or } \\
\text { cross } \\
\text { celled type }\end{array}$ & 4.16 & $\begin{array}{l}\text { Unicellular } \\
\text { elongated }\end{array}$ & $76.58 \%$ \\
\hline
\end{tabular}

Epidermal cells give rise to various types of multicellular and unicellular appendages or outgrowths differing in shape. Size and function- all these designated by the term trichome. The trichomes are generally elongated, unicellular form and possess glandular hairs. A typical glandular hair possesses a stalk and an enlarged terminal portion, which may be referred as gland. Active secretory cells glandular trichomes have dense protoplast and elaborate substances, such as volatile oils, resins and mucilages and gums.

\section{Results of Moisture Content}

Results from above experiment showed that mean moisture of rhizome in $Z$.montanum in the study was $76.58 \%$ (Table 1). Rhizome is considered a storage house of reserve food 
material and water enters into it through roots and therefore contains high level of moisture content.

\section{Preliminary Chemical Examinations:}

The phytochemical characteristics of Z.montanum plants tested were summarized in Table 2 . From the table, it could be seen that, proteins, carbohydrates, phenols and tannins, flavonoids and saponins were present $(+)$ in Z.montanum. Gums and mucilages were found to be absent (-) in plant extract.

Table 2. Results o phytochemical screening

\begin{tabular}{|l|l|l|}
\hline Phytoconsituent & Name of tests & Z. montanum \\
\hline Alkaloid & $\begin{array}{l}\text { Mayer's test } \\
\text { Wagner's test }\end{array}$ & $\begin{array}{l}+ \\
+\end{array}$ \\
\hline Carbohydrate & $\begin{array}{l}\text { Molish;s test } \\
\text { Fehling's test }\end{array}$ & $\begin{array}{l}+ \\
+\end{array}$ \\
\hline Glycosides & $\begin{array}{l}\text { Borntrager's } \\
\text { Test }\end{array}$ & + \\
\hline Saponins & Froth formation test & + \\
\hline Protein & Biuret test & + \\
\hline $\begin{array}{l}\text { Phenolic compounds and } \\
\text { tannins }\end{array}$ & $\begin{array}{l}\text { Gelatin test } \\
\text { Lead acetate test }\end{array}$ & + \\
\hline $\begin{array}{l}\text { Test for gum and } \\
\text { mucilages }\end{array}$ & Alcoholic ppt. Test & - \\
\hline Glycerol (lipid) & Copper sulphate test & + \\
\hline
\end{tabular}

\section{Estimation of Carbohydrate Content:}

The metabolism of Carbohydrate is utmost importance to organisms individually and collectively. Fundamentally, all the organic food stuffs are ultimately derived from the synthesis of carbohydrate through photosynthesis. The catabolism of carbohydrate provides major share of the energy requirement for maintenance of life and acts as energy reservoirs. One of pharmaceuticals importance is the fact that sugars unite with a wide variety of other compounds to form glycosides. Glucose is normally used to establish a calibration curve for the anthrone method and total sugars is expressed in terms of glucose.

The percentage of total carbohydrate content percentage in Z.montanum was found to have $49.8 \pm 0.06(\mathrm{mg})$ in Table 3.

Table 3. Total carbohydrate content in Z.montanum

\begin{tabular}{|l|l|l|}
\hline Plant sample & Plant parts & $\begin{array}{l}\text { Carbohydrate content } \\
\text { \% dry matter (mg ) }\end{array}$ \\
\hline Z. montanum & Rhizome & $49.8 \pm 0.06$ \\
\hline
\end{tabular}

[Mean \pm standard deviation (SD) of triplicate measurements]

\section{Total Polyphenolic Contents of the Plant Extract}

The polyphenolic content of Z.montanum varied between 0.32 and 0.40 showed in Table 4 . The total phenolics in methanolic, petroleum ether and chloroform extract were in range of 

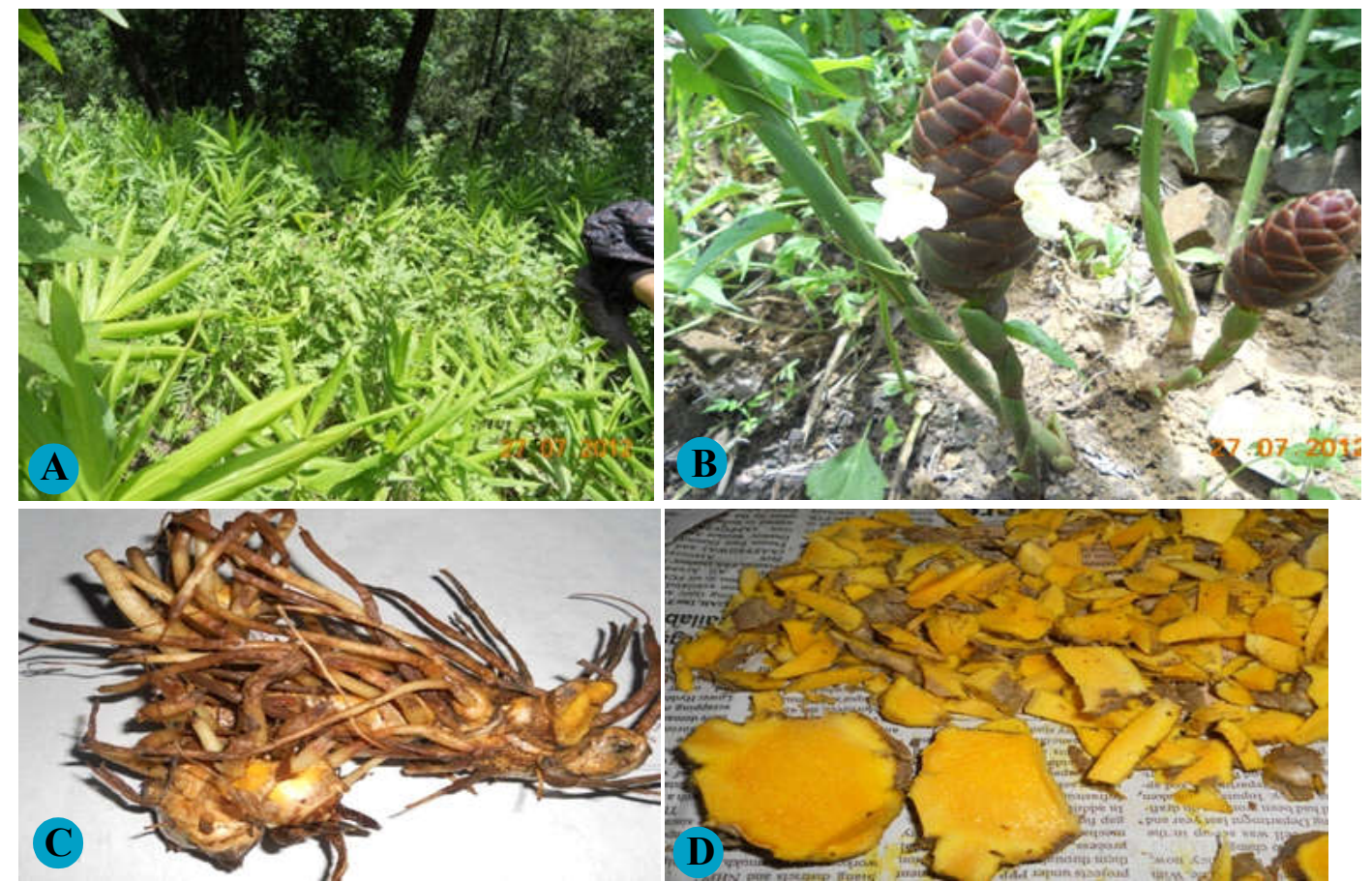

PLATE - I. Zingiber montanum: A. Plant in the wild; B. Plant with inflorescence; C. Rhizome; D. Flakes of rhizome showing intense yellow blaze
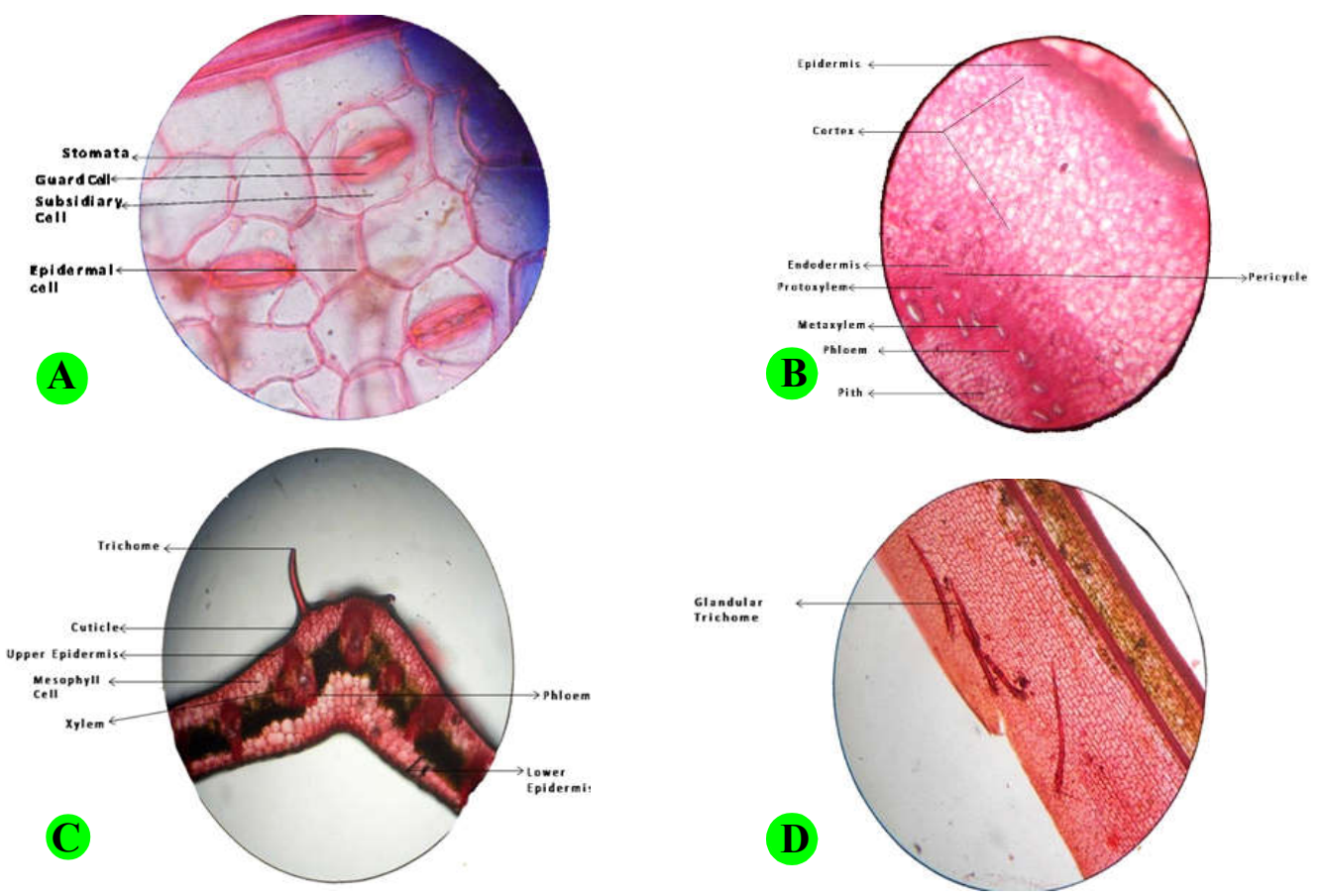

PLATE - II. Anatomical structures of Zingiber montanum: A. Epidermis with stomata; B. Transverse section of root; C. T.s. of leaf through the mid-vein; D. Leaf surface with trichomes 
$0.40 \mathrm{mg} \mathrm{GAE} / \mathrm{g}, 0.35 \mathrm{mg} \mathrm{GAE} / \mathrm{g}, 0.32 \mathrm{mg} \mathrm{GAE} / \mathrm{g}$ respectively. Among all three solvent extract the methanolic extract showed the highest amount of total phenolic content. The total phenolic content is expressed in gallic acid equivalents (GAE) is determined from regression equation of calibration curve $\left(\mathrm{y}=7.755 \mathrm{x}+0.0327, \mathrm{R}^{2}=0.9935\right)$.

Table 4. Total polyphenolic contents of the plant extract

\begin{tabular}{|l|l|l|l|l|}
\hline \multirow{2}{*}{ Name of Plant } & Parts & \multicolumn{3}{|c|}{ Uotal Phenolic Content (mg GAE/0.005g extracts) } \\
\cline { 3 - 5 } & Usethanol & $\begin{array}{l}\text { Petroleum } \\
\text { Ether }\end{array}$ & Chloroform \\
\hline Z. montanum & Rhizome & $\begin{array}{l}\mathbf{0 . 4 0} \pm \\
\mathbf{0 . 0 0 4}\end{array}$ & $\mathbf{0 . 3 5} \pm \mathbf{0 . 0 0 2}$ & $\mathbf{0 . 0 3 2} \pm \mathbf{0 . 0 0 3}$ \\
\hline
\end{tabular}

[Mean \pm standard deviation (SD) of triplicate measurements]

\section{Results of Antioxidant Assay}

Antioxidants help reduce the number of free radicals that form in the body, lower the energy levels of existing free radicals, and stop oxidation chain reactions to lower the amount of damage caused by free radicals. The antioxidants of food are thought to prevent diseases caused by oxidative stress (Cutler 1984; Frankel et al. 1993).

Table 5. Percentage inhibition of DPPH by plant extracts (at $30 \mathrm{~min}$ )

\begin{tabular}{|l|l|l|l|}
\hline \multirow{2}{*}{ Plants } & \multicolumn{3}{|c|}{ DPPH inhibition (\%) } \\
\cline { 2 - 4 } & Petroleum ether & Chloroform & Methanol \\
\hline Z. montanum & $\mathbf{2 9 . 1} \pm \mathbf{0 . 0 3}$ & $\mathbf{4 0 . 9} \pm \mathbf{0 . 0 4}$ & $\mathbf{8 4 . 3} \pm \mathbf{0 . 0 2}$ \\
\hline
\end{tabular}

[Mean \pm standard deviation (SD) of triplicate measurements]

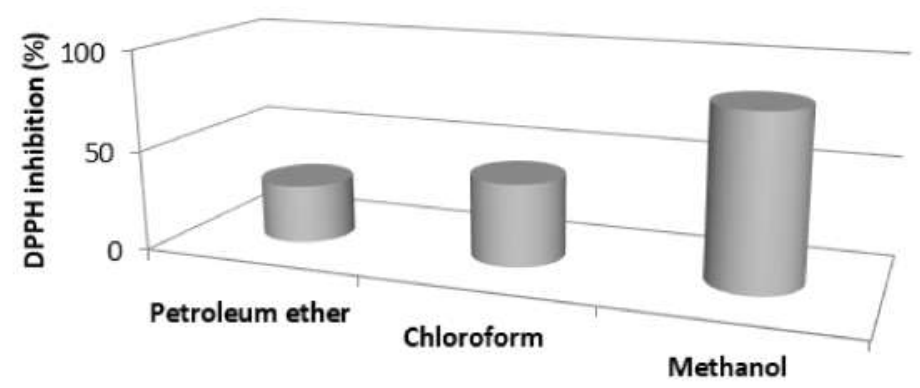

Figure 1. Percentage inhibition of DPPH by the extract of $Z$. montanum sample in different solvents

In Table 5, the scavenging activity of the DPPH radical due to its reduction by different plant extracts is illustrated. From this table it is seen that the methanolic extracts of all the plants were most effective DPPH radical scavengers.

This percentage can be considered as a full absorption inhibition of DPPH, because after completing the reaction the final solution always possesses some yellowish color and therefore its absorption inhibition compared to colorless methanol solution cannot reach 100 $\%$. The plant extracts of $Z$. montanum was good scavengers with highest inhibition of 84.3 $\%$ in methanolic extract (Table 5; Figure 1). Chloroform is slightly more effective radical scavengers than the petroleum ether as sample get soluble in the chloroform. 


\section{CONCLUSION}

The results revealed the presence of medicinally important constituents in the $Z$. montanum . Many evidences gathered in earlier studies which confirmed the identified phytochemical to be bioactive. Several studies confirmed the presence of these phytochemical contribute medicinal as well as physiological properties to the plants studied in the treatment of different ailments. The experimental plant sample is most potential in having antioxidant property, which may be utilized as prophylactic agents in drug formulations. The wild Z. montanum, due to the large scale disturbances by human being it is on the verge of extinction. Moreover, having active medicinal property, it could be source of employment to local people by cultivating in large scale, which is unknown to them and needed to be explored.

\section{LITERATURE CITED}

AOAC 1990. Methods of Analysis. $15^{\text {th }}$ Edn. Association of Official Analytical Chemists, Washington, DC.

Bakhru, H. K. 1993. Foods that Heal-The natural way to good health. Orient Paper Backs, Delhi.

Brand-Williams, W.; Cuvelier, M.E. \& Berset, C. 1995. Use of a Free Radical Method to Evaluate Antioxidant Activity. Lebensm Wiss Technology, Food Sci. Tech. 28: 25 - 30.

Casey, T.E.; Dougan, J.; Matthews, W.S. \& Nabney, J. 1971. Essential oil of “phlai”, Zingiber cassumunar Roxb., from Thailand. Trop. Sci 13(3): 198 - 203.

Cutler, R.G. 1984. Antioxidants, aging, and longevity. In: Pryor, W.A. (ed.), Free Radicals in Biology. Academic Press: New York. Pp $371-428$.

Evans, W.C. 1997. Trease and Evans Pharmacognosy. Harcourt Brace and company, Asia pvt. Ltd., Singapore.

Fransworth, N.R. 1969. Bilogical and phytochemical screening of plants. J. Pharma. Sc. 55: $225-255$.

Farnsworth, N.R. 1988. Screening of Plants for New Medicines. In: Wilson, E.O. (ed.), in Biodiversity, Chapter 9. National Academy Press, Washington DC.

Fisher, D.D. 1968. Protein stainng of ribboned epon ection for light microscopy. Histochem. 16: $81-96$.

Frankel, E.N.; Kanner, J.; German, J.B.; Parks, E. \& Kinsella, J.E. 1993. Inhibition of oxidation of human low-density lipoprotein by phenolic substances in red wine. Lancet, 341: 454 $-457$.

Gahan, P.B. 1984. Plant Histochemistry and Cytochemistry: An introduction. Academic presss, Florida, USA.

Kolkate, C.K. 1999. Practical Pharmacognosy, $4^{\text {th }}$ edn., Vallabh Prakashan Publication, New Delhi, India

Ramakrishnan, S.; Prasanan, K.G. \& Rajan, R. 1994. Text book of medical biochemistry. Orient Longman, New Delhi, India.

Ravikumar, S.; Surekha, R. \& Thavarajah, R. 2014. Mounting media: An overview. J NTR Univ.Health Sci, Suppl S1. $1-8$.

Salisbury, E.J. 1927. On the causes and ecological significance of stomatal frequency, with special reference to the woodland flora. Phil. Trans. Royal Soc. London, Series BBiological Sciences 216: 1 - 65. 
Singleton, V.L. \& Rossi, J.A. 1965. Colorimetry of total phenolics with phosphomolybdicphosphotungstic acid reagents. Amer. J. Ecol. Viticul. 16: $144-158$.

Small. J.C. 1913. Botanical source of Fetid Gum Resins. Pharm. J. 90: 287

Thimmaiah, S.K, 1999. Standard Methods of Biochemical Analysis. Kalyani Publishers, New Delhi.

Wagner, H. 1993. Pharmazeutische Biologic $5^{\text {th }}$ edn., UF. 15 BN 3-437-20 498-X. Gustav fisher Vwelag, Stuttgart, Germany.

Wallis, T.E. 1953. Practical Pharmacognosy. $6^{\text {th }}$ edn. J.A. Churchil ltd., London. Pp. $139-$ 140.

Wallis,T.E. 1985. Textbook of Pharmaognosy. $5^{\text {th }}$ edn. S.K. Jain publication, New Delhi, India

Whistler, R.L. \& Bemiller, J.N. 1993. Industrial Gums; Polysaccharides and their Derivatives. Acdemic Press, London, U.K.

www.icssr.org/Executive\%20Summary\%20Lower\%20Subansiri.pdf

www.theplantlist.org. 